\title{
Study of coral reef for marine ecotourism development based on region suitability and carrying capacity in Marsegu Island Nature Tourism Park, Maluku, Indonesia
}

\author{
HENDERINA LELLOLTERY ${ }^{1}$, SATYAWAN PUDYATMOKO ${ }^{2}$, CHAFID FANDELLI ${ }^{2}$, MUHAMAD BAIQUNI ${ }^{3}$ \\ ${ }^{1}$ Forestry Program, Faculty of Forestry, Universitas Gadjah Mada. Jl. Bulaksumur, Sleman 55281, Yogyakarta, Indonesia, Tel.: +62-274-550541; Fax.: \\ +62-274-550543, `email: h_lellol@yahoo.com, henderina.lelloltery@mail.ugm.ac.id \\ ${ }^{2}$ Department of Forestry, Faculty of Forestry, Universitas Gadjah Mada. Jl. Bulaksumur, Sleman 55281, Yogyakarta, Indonesia \\ ${ }^{3}$ Department of Geography, Faculty of Geography, Universitas Gadjah Mada. Jl. Teknika, Sekip Utara, Sleman 55281, Yogyakarta, Indonesia
}

Manuscript received: 20 March 2018. Revision accepted: 18 May 2018.

\begin{abstract}
Lelloltery H, Pudyatmoko S, Fandelli C, Baiquni M. 2018. Study of coral reef for marine ecotourism development based on region suitability and carrying capacity in Marsegu Island Nature Tourism Park, Maluku, Indonesia. Biodiversitas 19: 1089-1096. The objectives of the research were to identify the potential of marine natural resources as the object and attraction of marine ecotourism, and to compile the development plan at Marsegu Island Nature Tourism Park (NTP) based on the Tourism Suitability Index (TSI) and carrying capacity. Data collection included coral reef and fish type using the Line Intercept Transect (LIT) method. Data were analyzed using the tourism suitability index and analysis of physical carrying capacity of the area. The results showed the potential of marine resources covering the coral reefs including 45 species within 23 genera from 14 families with 12 coral lifeforms. A high diversity of reef fish was found, documenting 129 species of fish within 60 genera from 22 families. The analysis result of the tourism suitability index (TSI) in the snorkeling category was $74.79 \%$ with a carrying capacity of 4,092 person(s)/day and the TSI of diving was $67.32 \%$ with a physical carrying capacity of 1,855 person(s)/day. The analysis showed that the area around Marsegu Island NTP is "suitable" for ecotourism activities and does not exceed the carrying capacity of the area. The strategy for marine ecotourism management needs to be completed, including elements such as determining the number of tourists that can be supported per day (based on limiting the number of divers/snorkelers per day), implementing boat moorings so coral is not damaged by anchors, making sure tourism operators brief divers/snorkelers not to touch, stand on or break the coral, and ensuring the tour operator is the organization responsible for the continuous monitoring of marine ecotourism activities and protection of dive sites.
\end{abstract}

Keywords: Carrying capacity, coral reefs, marine ecotourism, nature tourism park, reef fish, tourist suitability index

\section{INTRODUCTION}

Marsegu Island Nature Tourism Park is located in West Seram District of Maluku Province with an area of 9,023 Ha (NRCC 2010). This area is a Marine Conservation Area that has coastal resources in the form of coral reefs, coral fish, mangrove, seagrass and various other marine biotas. This area is located between Marsegu Island and Osi Island, and is surrounded by several small islands such as Buntal Island, Bird Island and Tatumba Island, all with beautiful and interesting sea-scapes. However, the potential of these marine resources is still under threat due to both natural and human factors. Human factors are most associated with fishing activities, which are being conducted in an environmentally unsustainable manner by the surrounding communities. This condition is common in almost all coastal communities because the majority of coastal communities have a high dependence on and consumption of the surrounding natural resources (Dahuri 2003). To minimize the impact of coastal resource damage, one of the preventive measures is through the utilization of environmental services based on marine ecotourism. This is supported by the potential for diversity in the natural resources of small islands that are abundant and ideal for development as ecotourism destinations (Baiquni 2013). Walters and Samways (2001), asserted that marine ecotourism contributes to the protection of coastal and marine ecosystems and has an impact in supporting the economy of local communities. In line with this, research conducted by Honey (2006) and Rhormens et al. (2017), asserted that ecotourism has the potential to serve as a means of education in enhancing the conservation action of sustainable biodiversity and cultural conservation that can improve the livelihoods of surrounding communities.

Currently, Marsegu Island NTP has become one of the marine ecotourism destinations in Maluku. This is indicated by the presence of domestic and foreign tourists in a limited quantity and with activities more focused on enjoying the natural scenery, coastal nature tourism, and snorkeling and diving (Tourism Office of Maluku 2015). However, Marsegu Island NTP is not yet under optimal management as a marine ecotourism destination.

This is due to the lack of supporting facilities in the form of human resources and government support. Additionally, there is yet to be any comprehensive management of the area at potential points where resources are concentrated. The arrangement of areas is important so that it becomes a guide for managers and tourists to 
perform various activities. To determine the best plan, we need to further study the suitability of the region and its carrying capacity as the foundation of policy development for sustainable marine ecotourism.

The objectives of this research are (i) to identify the potential of marine resources in the form of coral reefs and reef fish as the object and attraction of marine ecotourism, and (ii) Prepare the design of marine ecotourism development at Marsegu Island NTP based on the tourism suitability index and the carrying capacity of the area.

\section{MATERIALS AND METHODS}

\section{Location and time of research}

This research was conducted in an area of Marsegu Island Nature Tourism Park (NTP), Western Seram District, Maluku, Indonesia, specifically Marsegu Islands for six months from June to December 2016. Location map of the study sample area is presented in Figure 1.

\section{Tools and materials}

Tools and materials used in this study are Map of Marsegu Island NTP area, GPS, Coral reef and coral fish manuals, SCUBA equipment, meter roll, underwater stationery (paper, pencil and baseboard), underwater camera, current meter, thermometer, refractometer, Secchi disk, and aquatic resources including coral reefs and coral fish.

\section{Data collections technique}

The data was collected in the form of primary and secondary data. Primary data was obtained directly from the location through observation, survey and interview. The secondary data was obtained from literature study and related institutions.

Coral reefs and fish data collection was conducted around Marsegu Island, with consideration that the area was a utilization zone of Marsegu Island NTP. To get coral reefs data and coral reef ecosystem components a line intercept transect (LIT) method was utilized at 6 observation stations. The shape of coral growth (lifeform) and percentage of coral cover (English et al. 1997) was determined. The observation stations were determined prior to field observations by looking at the width of the reef using satellite images. The observation stations were located around Marsegu Island and consisted of 50 meters long transects, with the distance between stations varying along the boundary line of the coral reef and sea level. Coral observations recorded all forms of coral growth and coral species.

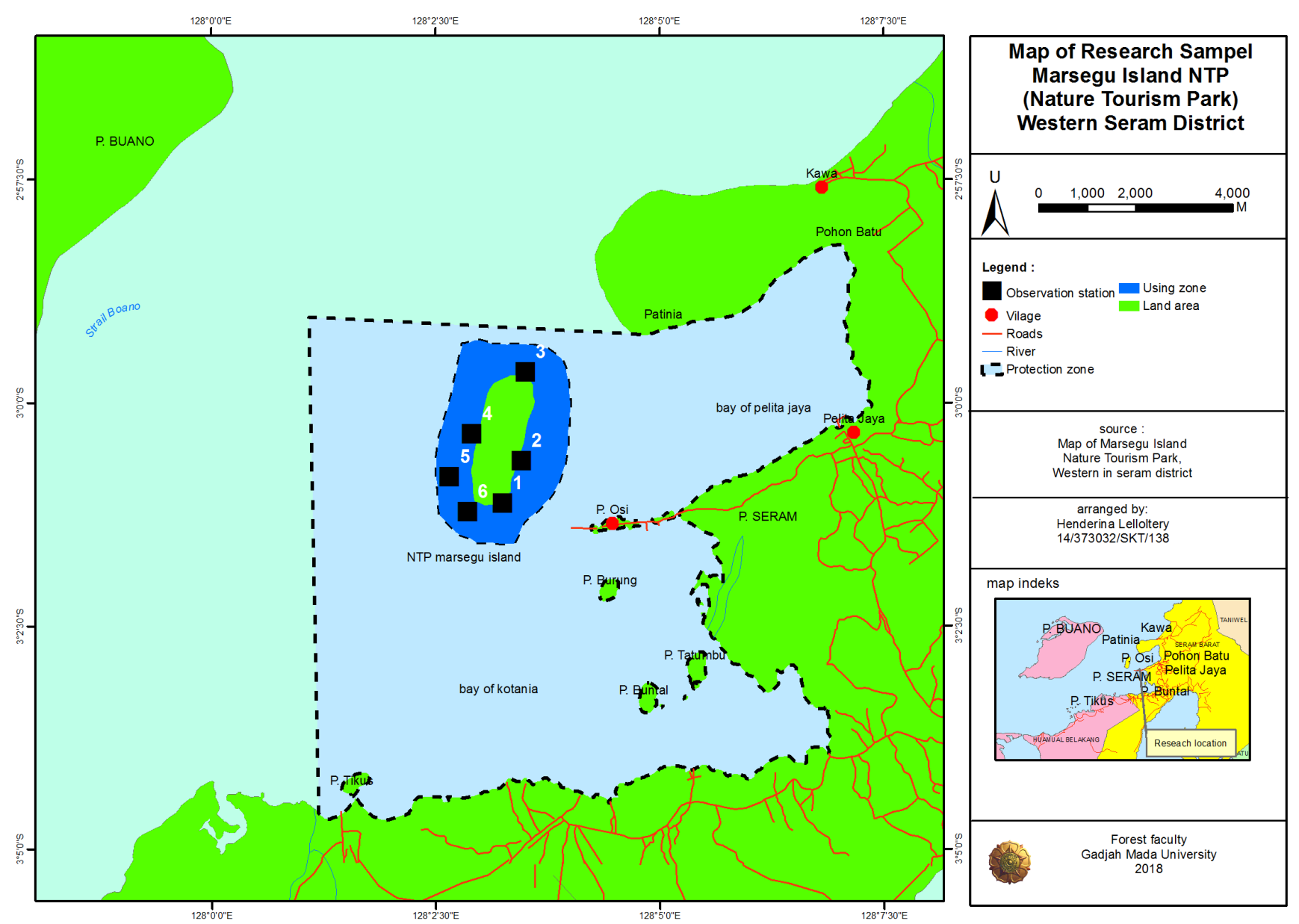

Figure 1. Study site in Marsegu Island NTP, Western Seram District, Maluku, Indonesia 
Coral fish data were collected using the Underwater Visual Census (UVC) method (English et al. 1997). The UVC method is done simultaneously with the LIT method, and consisted of a transect length of 50 meters, and a transect width of 2.5 meters on the left side and on the right side of the transect. During observations, the total, types, genus and family of the fish was recorded.

Measurements of environmental variables were carried out at each observation station including waters transparency, current velocity, temperature, and salinity. The coral flat width was measured based on Landsat ETM $7+$ 2006. The result of environmental parameter measurements was then included in the maritime ecotourism suitability matrix to determine the value of the snorkeling tour suitability index based on Yulianda (2007).

\section{Data analysis}

Analysis of coral reef and coral fish

Data on coral reef closure conditions were analyzed using Lifeform analysis of the following equation: (English et al. 1997):

$$
\text { Percentage of coral cover }=\frac{\text { Length of each ecology }}{\text { Transect length }} \times 100 \%
$$

After the percentage of coral cover was calculated, the coral reef condition was determined based on Gomez and Yap (1988) criteria of the Coral Reef Damage Standard, which consists of four categories: excellent $(75-100 \%)$, good (50-74.9\%), medium (25-49.9\%), bad (0-24.9\%).

Reef fish data from observations was classified as fish diversity data. Fish diversity data were then analyzed descriptively to determine the species, the number of species, the family and the classification of the fish species based on the fish species protection status (IUCN red list).

\section{Analysis of tourism suitability matrix}

Analysis of the tourism suitability matrix for snorkeling and diving utilized the manual of tour suitability index measurements developed by Yulianda (2007).

The suitability of snorkeling tours utilized 7 parameters and was grouped into 4 categories (Table 1). The suitability of diving tours utilzied 6 parameters and was grouped into 4 categories (Table 2).

Suitability analysis was conducted to determine the suitability of the area for the development of tourism. This was done to determine the ability of the area to support the various activities that would be undertaken in the area. The parameters used for the suitability of marine tourism by Yulianda (2007) were as follows:

$$
T S I=\sum\left[\frac{N i}{N m a k s}\right] \times 100 \%
$$

Where:

TSI : Tourism suitability index

$\mathrm{Ni}$ : The-i parameter value (weight $\mathrm{x}$ score)

Nmax : The maximum value of a category (snorkeling and diving)

The suitability class for diving and snorkeling were as follows:

S1 : very suitable, by TSI $83-100 \%$;

S2 : suitable, by TSI $50-<83 \%$;

S3 : conditional suitable, by TSI $17-<50 \%$ and

$\mathrm{N}$ : not suitable, by TSI $<17 \%$.

\begin{tabular}{|c|c|c|c|c|c|c|c|c|c|}
\hline Parameter & Weight & $\begin{array}{c}\text { Category } \\
\text { (S1) }\end{array}$ & Score & $\begin{array}{c}\text { Category } \\
\text { (S2) }\end{array}$ & Score & $\begin{array}{c}\text { Category } \\
\text { (S3) }\end{array}$ & Score & $\begin{array}{c}\text { Category } \\
(\mathrm{N})\end{array}$ & Score \\
\hline Water transparency $(\mathrm{m})$ & 5 & 100 & 3 & $80-<100$ & 2 & $20-<50$ & 1 & $<20$ & 0 \\
\hline Coral cover $(\%)$ & 5 & $>75$ & 3 & $>50-75$ & 2 & $25-50$ & 1 & $<25$ & 0 \\
\hline Lifeform number & 5 & $>12$ & 3 & $<7-12$ & 2 & $4-7$ & 1 & $<4$ & 0 \\
\hline Coral fish species & 3 & $>50$ & 3 & $30-50$ & 2 & $10-<30$ & 1 & $<10$ & 0 \\
\hline Current velocity $(\mathrm{cm} / \mathrm{sec})$. & 1 & $0-15$ & 3 & $>15-30$ & 2 & $>30-50$ & 1 & $>50$ & 0 \\
\hline Reef depth $(m)$ & 1 & $1-3$ & 3 & $>3-6$ & 2 & $>6-10$ & 1 & $>10-<1$ & 0 \\
\hline Reef width (m) & 1 & $>500$ & 3 & $>100-500$ & 2 & $20-100$ & 1 & $<20$ & 0 \\
\hline
\end{tabular}

Table 1. Matrix of land suitability for snorkeling tourism (Yulianda 2007)

Note: Number $\mathrm{N}$ Max $=57 ; \mathrm{N}=$ score $\mathrm{x}$ weight

\begin{tabular}{|c|c|c|c|c|c|c|c|c|c|}
\hline Parameter & Weight & $\begin{array}{c}\text { Category } \\
\text { (S1) }\end{array}$ & Score & $\begin{array}{c}\text { Category } \\
\text { (S2) }\end{array}$ & Score & $\begin{array}{c}\text { Category } \\
\text { (S3) }\end{array}$ & Score & $\begin{array}{c}\text { Category } \\
(\mathrm{N})\end{array}$ & Score \\
\hline Water transparency (m) & 5 & $>80$ & 3 & $50-80$ & 2 & $20-<50$ & 1 & $<20$ & 0 \\
\hline Coral cover $(\%)$ & 5 & $>75$ & 3 & $>50-75$ & 2 & $25-50$ & 1 & $<25$ & 0 \\
\hline Lifeform number & 3 & $>12$ & 3 & $<7-12$ & 2 & $4-7$ & 1 & $<4$ & 0 \\
\hline Coral fish species & 3 & $>100$ & 3 & $50-100$ & 2 & $20-50$ & 1 & $<20$ & 0 \\
\hline Current velocity $(\mathrm{cm} / \mathrm{sec})$. & 1 & $6-15$ & 3 & $15-20$ & 2 & $>20-30$ & 1 & $>30$ & 0 \\
\hline Reef depth (m) & 1 & $0-15$ & 3 & $15-30$ & 2 & $>30-50$ & 1 & $>50$ & 0 \\
\hline
\end{tabular}

Table 2. Matrix of suitability for diving tourism (Yulianda 2007)

Note: Number $\mathrm{N}$ Max $=57 ; \mathrm{N}=$ score $\mathrm{x}$ weight 
Analysis of area carrying capacity

The physical carrying capacity can be analyzed with the equation (Douglas 1975):

$$
P C C=A x \frac{V}{a} x R f
$$

Where:

PCC : Physical carrying capacity (person $/ \mathrm{m}^{2} /$ day)

A : Area used for tourism $\left(\mathrm{m}^{2}\right)$

$\mathrm{V} / \mathrm{a}$ : Number of visitors $/ \mathrm{m}^{2}$ (person $/ \mathrm{m}^{2}$ )

$\mathrm{Rf}$ : Rotation factor (magnitude $\mathrm{Rf}$ : duration of opening time for area ecotourism/time of average visit time) visits (Fandeli, 2002)

\section{RESULTS AND DISCUSSION}

\section{Potential of marine resources in Marsegu Island Nature Tourism Park \\ Condition and potential of coral reefs}

Based on the data of Citra analysis, the extent of coral reefs in Marsegu Island NTP was 1,557.68 Ha while the coral reef area within the utilization zone was $432.52 \mathrm{Ha}$ The observation of coral reefs in the utilization zone around Marsegu Island found 45 species belonging to 23 genera and 14 families. Coral cover was found in the form of hard coral covering Acropora and non-Acropora, dead coral algae, algae, sponge, soft coral, other biotas (OT) and abiotic (sand and coral fracture).

The species of coral reefs and the percentage of benthic component coverings in the waters around Marsegu Island are presented in Figure 2. Based on Figure 2, hard coral cover consisting of Acropora and non-Acropora occupied the highest percentage at $69.86 \%$ and was categorized as "Good". The results of this study are comparable with Sitanala Research (2016) in the Kasa Island Marine Nature Tourism Park which showed that the coral cover percentage of $77.56 \%$ was categorized as "Good". This is comparable to the research on Marsegu Island because these two islands are still in a similar ecological region.

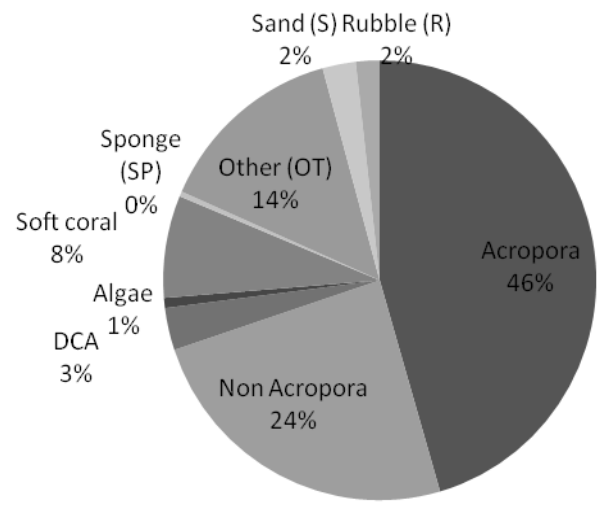

Figure 2. Benthic covering component at Marsegu Island Nature Tourism Park, Western Seram District, Maluku, Indonesia
Live reefs dominated coral benthic cover, where Acropora was widely dispersed, occupied large areas spread over 2 to 20 meter deep, and had various colors. Acropora live corals with branched growth forms (ACB) occupy large areas and have attractive colors. Tabulate Acropora (ACT) had large colonies and non-Acropora species like Coral Submassive (CS) live on the reef wall and have attractive colors like red which give a beautiful impression. Based on the assessment of live coral cover, it was found that the condition and health of the coral ecosystem were in the "Good" category. Overall a total number of 12 lifeforms were found.

\section{Potential and condition reef fish}

Results of observation of the species of fish found 146 species, 64 genera, and 21 families. When classified based on the function and role of the fish (major, target, or indicator), 81 species of major fish were found (55.48\%), 49 species of target fish were found (33.56\%) and 16 species of indicator fish were found (10.95\%). Species of major fish (ornamental fish) were generally dominated by the family Pomacentridae, the target fish (fish consumption) was dominated by the Caesionidae, Lutjanidae, and Serranidae families. Indicator fish generally have a striking and attractive shape and color, and become an attraction for tourists. The species of indicator fish found in this aquatic ecosystem indicated that the coral reefs are in good condition. The most common indicator fish came from the Chaetodontidae family, such as Chaetodon sp. and $H$. varius. A species of Napoleon fish (C. undulates) is a protected species due to its threatened status (IUCN), and was found within the Marsegu Island NTP. The existence of this increasingly scarce fish, can be an attraction for tourists who want to see it directly in its habitat.

\section{Marine conditions around Marsegu Island Nature Tourism Park}

The physical and chemical water conditions around Marsegu Island were normal and the average velocity was $0.16 \mathrm{~m} / \mathrm{s}$. Water temperature averaged $28,66^{\circ} \mathrm{C}$. This temperature was very good for tropical marine organisms and suitable for tourism activity. Nontji (2005) asserted that Indonesian sea surface temperatures generally range from $26-29^{\circ} \mathrm{C}$ and affect the growth of marine biological resources such as coral reefs and fish. The waters around Marsegu Island was within that temperature range.

Water transparency is closely related to marine ecotourism activities as it relates to the convenience of snorkeling and diving activities for tourists. The average water transparency is 12 meters. According to the Decree of the Minister of Environment No. 51 of 2004 on Water Quality Standard, the water transparency for marine tourism is $>6 \mathrm{~m}$. Thus the high water transparency around Marsegu Island can support marine tourism activities because visitors can enjoy a farther underwater viewing distance.

Salinity, or dissolved salt content in waters, is an environmental parameter that affects marine biological processes such as growth rate, quantity of food consumed, and survival of organisms. The results of salinity 
measurements from the surface to a depth of 39 meters ranged from 34.00 to $34.15 \%$, averaging $34.10 \%$, which is very good for marine organisms. This is in accordance with the opinion of Bengen (2002), which stated that the salinity value is good for marine biota life ranged from 30 to $36 \%$. In general, the condition of waters around Marsegu Island is still in good condition and there is no pollution or visible garbage or waste from community activities in the waters, therefore it is suitable for marine tourism activities.

\section{Marine tourism suitability}

Suitability of snorkeling and diving ecotourism

The results of the snorkeling and diving ecotourism suitability analysis are presented in Table 3 and Table 4 and Figure 3. Based on Table 3, the tourism suitability index (TSI) for the snorkeling category at all observation stations was "appropriate" with an average TSI value of $74.79 \%$ with an area of 102.3 ha. As seen in Table 4 , the ecotourism suitability index for the category of "diving" at all observation stations was "appropriate" with an average TSI value of $67.32 \%$, with a utilization area of 46.37 ha. Snorkeling and diving activity maps are shown in Figure 3.

\section{Physical carrying capacity}

The results showed that the area used for snorkeling activities was 1,023 ha with a carrying capacity of 4,092 people/ha. Diving activity used an area of 46.37 ha and has a carrying capacity of 1,855 persons/day. The calculation of the carrying capacity of the region is presented in Table $5 . \square$
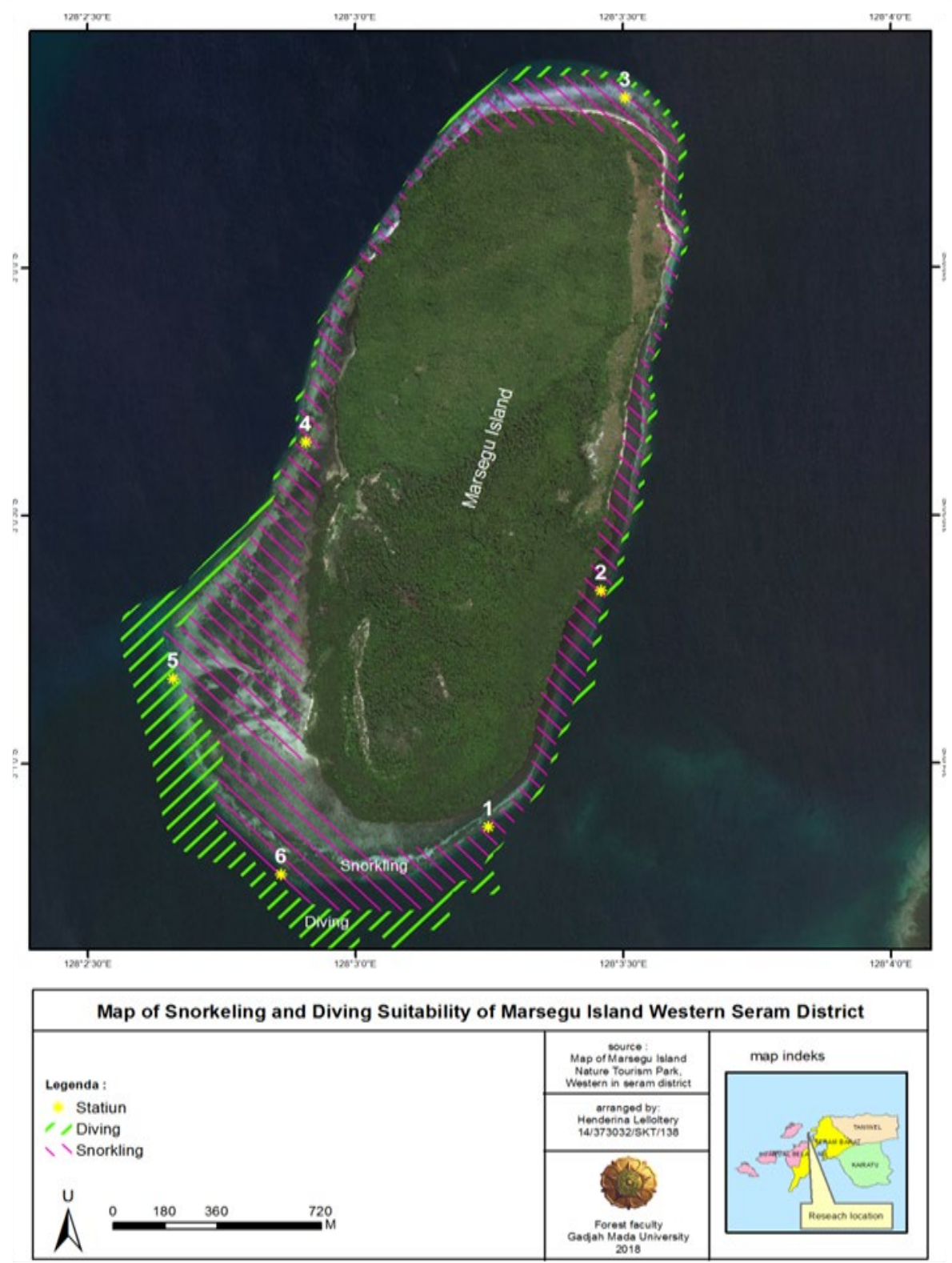

Figure 3. Map of snorkeling and diving activity location in Marsegu Island Nature Tourism Park, Western Seram District, Maluku, Indonesia 
Table 3. Suitability of snorkeling ecotourism at each observation station of Marsegu Island Nature Tourism Park, Western Seram District, Maluku, Indonesia

\begin{tabular}{cccl}
\hline $\begin{array}{c}\text { Observation } \\
\text { Station }\end{array}$ & $\begin{array}{c}\text { Suitability } \\
\text { Index (\%) }\end{array}$ & $\begin{array}{c}\text { Category } \\
\text { Suitability }\end{array}$ & Description \\
\hline 1 & 73.68 & S2 & Area of \\
2 & 84.20 & S2 & acreage $=$ \\
3 & 70.18 & S2 & $102.30 \mathrm{Ha}$ \\
4 & 72.00 & S2 & \\
5 & 68.00 & S2 & \\
6 & 80.70 & S2 & \\
Average & 74.79 & & \\
\hline
\end{tabular}

Table 4. Suitability of diving ecotourism at each observation station of Marsegu Island Nature Tourism Park, Western Seram District, Maluku, Indonesia

\begin{tabular}{cccl}
\hline $\begin{array}{c}\text { Observation } \\
\text { Station }\end{array}$ & $\begin{array}{c}\text { Suitability } \\
\text { Index (\%) }\end{array}$ & $\begin{array}{c}\text { Category } \\
\text { Suitability }\end{array}$ & Description \\
\hline 1 & 59.30 & $\mathrm{~S} 2$ & Area of \\
2 & 75.90 & $\mathrm{~S} 2$ & acreage $=$ \\
3 & 66.70 & $\mathrm{~S} 2$ & $46.37 \mathrm{Ha}$ \\
4 & 72.20 & $\mathrm{~S} 2$ & \\
5 & 55.60 & $\mathrm{~S} 2$ & \\
6 & 74.10 & $\mathrm{~S} 2$ & \\
Average & 67.32 & & \\
\hline
\end{tabular}

Table 5. Carrying capacity of snorkeling and diving areas

\begin{tabular}{lcccc}
\hline $\begin{array}{c}\text { Type of } \\
\text { activity }\end{array}$ & $\begin{array}{c}\text { Wide area } \\
\text { (hectare) }\end{array}$ & $\begin{array}{c}\text { Space needs } \\
(\mathbf{V} / \mathbf{a}) \\
\text { person/m }\end{array}$ & Rf & $\begin{array}{c}\text { PCC } \\
\text { (person/ } \\
\text { day) }\end{array}$ \\
\hline Snorkeling & 1,023 & $1 / 500=0.002$ & 2 & 4,092 \\
Diving & 46.37 & $1 / 1,000=0.001$ & 4 & 1,855 \\
\hline
\end{tabular}

\section{Discussion \\ Potential of coral reef and reef fish}

Generally, coral reefs in Indonesia are categorized coral reefs (fringing reef) i.e. coral reefs that exist along the coast, growing on the surface to the sea not more than 40 meters from shore (Djunaedi, 2011). Generally, coral reefs in the waters around Marsegu island include this type of fringing reef, from the shore to sea form reef flats (NRCC, 2010). The results of this research showed that live coral cover occupied the highest percentage $(69.86 \%)$ of the reefs and was categorized as "good". The existence of coral species with various forms of growth such as branching Acropora (ACB), Tabulate Acropora (ACT), encrusting Acropora (ACE), submassive Acropora (ACS), and digitate Acropora (ACD) with attractive colors gives a very beautiful and attractive impression to tourists. These coral formations will be an attraction for tourists, especially those who will be snorkeling and diving. Burke et al. (2011) confirmed that coral reefs were vital to tourism interests because their beauty was an important tourist attraction for water sports, such as scuba diving. Surpriharyono (2007) added that coral reefs have undoubted value because the mainstay of marine tourism was the beauty and uniqueness of the coral reefs. $\square$

Brander et al. (2007), asserted many tourist activities in coastal areas depend on the quality of coral reefs. Marine tourism activities such as swimming, snorkeling, diving, and enjoying the coastal seascapes may be disrupted in the event of a decline in coral reefs (Principe et al., 2012). Based on the assessment of live coral cover, the condition and health of the coral ecosystem are in the "good" category. This is evident from the different coral shapes that form complex habitat structures for reef fish and invertebrates. The more complex the habitat, a more extensive range of species can be supported and the healthier the coral reefs will be. $\square$

A total number of 12 coral lifeforms were identified. The abundance of lifeforms will provide an attraction for tourists. This is in line with Planthong et al. (2000) which stated that for marine tourism, a variation in type of coral lifeform is needed to maximize enjoyment by tourists.

Others abiotic coral cover components such as sand, dead coral covered Algae (DCA) and coral fragments/rubble (R) can still be found on the western side of Marsegu Island. This indicates that there were disruptions to the coral reefs. Disruptions to coral reefs generally come from community activities such as fishing. Disturbances were seen from coral fractures at two observation stations (station 4 and station 5). However, it can be seen that the damaged coral reefs have begun to recover, with the emergence of young coral colonies in several locations.

The main conservation measures within the living habitat and coral reef development are preventive actions against structured environmental damage (UNEP-WCMC, 2006). In addition, preventive action in the management of marine conservation areas needs to be protected against observation stations, especially in the development of marine ecotourism for diving and snorkeling activities. $\square$

The existence of coral reefs with a high diversity of coral fish species, especially those with a variety of colors and forms, is of interest to marine tourism attraction. Napoleon fish (C. undulates) is a species of Endangered fish (Endangered/EN). Due to the low numbers of this species found in natural habitats, it is protected by the government and not widely traded (Appendix II). The existence of this increasingly scarce fish can be an attraction for tourists who want to see it directly in nature. Based on the potential of reef fish, it is necessary to protect the area through the limiting of fishing activities. Currently, the area is still open access for fishing by the surrounding community. Wabnitz et al. (2018), asserted that protection of an area can minimize the loss of endemic fish species in nature.

This requires intensive supervision through periodic monitoring, increasing the number of personnel, involving the surrounding community, and establishing regulations related to the utilization of the area. Walters and Samways 
(2001) report that monitoring the impact of human activities on coral reefs was needed to protect coral reef ecosystems with a sustainable management approach. Rhormens et al. (2017), asserted that continuous environmental monitoring between partnerships and stakeholders is essential in the management of marine ecotourism. $\square$

\section{Development of marine ecotourism based on suitability of} tourism and carrying capacity

To optimize the benefits of the area, we conducted a tourism suitability analysis, especially for snorkeling and diving (Table 4 and Table 5). The results indicated the area was classified as 'Suitable' (S2), meaning that the utilization zone can support snorkeling and diving ecotourism activities. The results of the TSI on Marsegu Island of Maluku were comparable to the results found by Arif et al. (2013), which showed that the TSI of snorkeling and diving in Lara Island in Southeast Sulawesi ranged from 60 to $80 \%$, and was classified in the "Suitable" category $(\mathrm{S} 2)$.

The recommended location for snorkeling and diving is the northeast side of Marsegu Island, at station 1, station 2 and station 3. The highest coral cover percentage was at station 2 with $80.12 \%$ and was dominated by hard coral with coral reefs of $500-800 \mathrm{~m}$ in width. A total of 12 lifeforms and an average velocity of $16.7 \mathrm{~m} / \mathrm{sec}$ further support snorkeling and diving activities The low current velocity is an ideal requirement for diving tours because this directly relates to the comfort and safety of tourists (Arifin et al. 2002). The physical condition of these waters supports snorkeling and diving activities, so it can be done in the west season (December to March) and the east season (May to October).

On the western side to the south of Marsegu Island (station 4, station 5 and station 6), the water transparency was around $12 \mathrm{~m}$ and the coral reef range from 700 to 900 meters, but the high current velocity (averaging 25.23 $\mathrm{m} / \mathrm{sec}$ ) and presence of a rip current on the south side indicate seasonal patterns need to be accounted for when snorkeling and diving. Based on the results of this research, all observation stations are suitable locations for marine ecotourism activities, but must be well managed to prevent damage to the coral reefs at the dive stations. Tratalos and Austin (2001) asserted that excessive dive activity will have an impact on coral damage, therefore the dive spots need to be well managed. Wabnitz et al. (2018), asserted that to keep the coral reef ecosystems sustainable, tourists need to reduce direct contact with coral reefs and reef fish consumption must be reduced by both tourists and local communities.

Tourism area management needs to calculate the carrying capacity of the area to prevent environmental damage and environmental quality degradation. The carrying capacity of the area is related to the ability of the area to accommodate various tourist activities. Brander et al. (2007), asserted that marine ecotourism should be conducted within the limits of power, as it does not directly correlate positively with coral reefs.

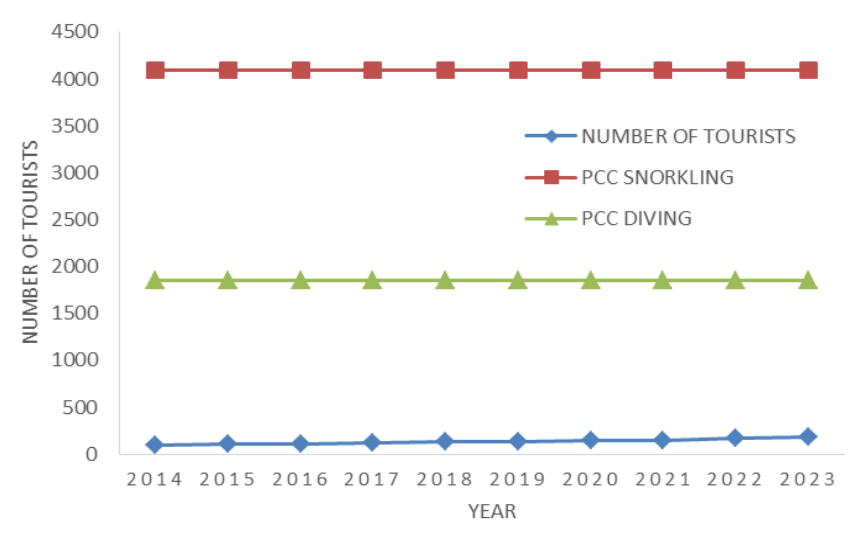

Figure 4. Comparison of number of tourist and area carrying capacity for snorkeling and diving at Marsegu Island Nature Tourism Park, Western Seram District, Maluku, Indonesia

Based on the tourist data from the last 2 years (20142015), it can be seen that the number of tourists visiting Marsegu Island Nature Tourism Park averaged as many as 96 people per year. If based on the assumption of an increase in the number of tourists as much as $7 \%$ for 10 years to come, the carrying capacity of snorkeling and diving areas or the carrying capacity of the area will not be exceeded, as presented in Figure 4.

Based on the graph in Figure 4, it can be seen that the current number of active tourists has not exceeded its carrying capacity, but to prevent over capacity and degradation of marine environmental quality, a strategy for marine ecotourism management needs to be completed and implemented; including limiting the number of divers/snorkelers per day, implementing boat moorings so coral is not damaged by anchors, making sure tourism operators brief divers/snorkellers not to touch, stand on, or break the coral, ensuring the tour operator is the organization responsible for the continuous monitoring of marine ecotourism activities and protection of dive sites. Currently, for marine ecotourism activities, the number of tourists is still limited so there is no garbage or plastic waste around the activity area, but the provision for places of waste in the tourist locations must be implemented. Overall, Marsegu Island Nature Tourism Park is suitable for marine ecotourism, maintaining the sustainability of coral reef and coral fish resources, and the conservation of aquatic ecosystems. $\square$

In conclusion, potential coral reefs in Marsegu Island consist of 45 species, 13 genera, and 14 families with coral cover of $69.86 \%$, classified under "Good" condition, and including 12 coral lifeforms. There is an abundance of fish species consisting of 146 species, 64 genera, and 21 families with 16 indicator fish species (these serve as an indicator of the condition of coral reefs). The tourism suitability index (TSI) for snorkeling and diving was $74.79 \%$ and $67.32 \%$ respectively. The carrying capacity of snorkeling and diving was calculated as 4,092 persons/day and 1,855 persons/day respectively. This demonstrates that Marsegu Island Nature Tourism Park is "appropriate" for marine ecotourism activities without exceeding the 
carrying capacity. A strategy for marine ecotourism management needs to be completed, including elements such as limiting the number of divers/snorkelers per day, implementing boat moorings so coral is not damaged by anchors, making sure tourism operators brief divers/snorkellers not to touch, stand on, or break the coral, and ensuring the tour operator is the organization responsible for the continuous monitoring of marine ecotourism activities and protection of dive sites.

\section{ACKNOWLEDGEMENTS}

This study is part of a dissertation funded by the General Directorate of Higher Education (DIKTI) Indonesia, Number: 1420/E4.4/2014. The authors are also thankful to the staff of Department of Conservation, Faculty of Forestry, Gadjah Mada University, Yogyakarta, Indonesia and also to all people involved in the Indonesia Institute of Sciences, Ambon for providing necessary logistics during the sampling work and sample analysis.

\section{REFERENCES}

Arif AB, Mustafa A, Ketjulan R. 2013. Study of regional potential and conformity of coral reef ecosystems in Lara Island for marine ecotourism development. Jurnal Mina Laut Indonesia 1 (1): 49-60. [Indonesian]

Arifin T, Bengen DG, Pariwono J. 2002. Evaluation of suitability of coastal area of Palu Bay for maritime tourism development. Jurnal Pesisir dan Lautan 4: 25-35. [Indonesian]

Baiquni M. 2013. Geostrategy of Indonesia and Pacific Islands on Ecotourism Collaboration.Ecotourism Destinations in Archipelago Countries. Gadjah Mada University Press, Yogyakarta.

Bengen DG. 2002. Synopsis of Coastal and Marine Resources Ecosystem and Principles of Management. Center for Coastal and Marine Resource Studies, Bogor Agricultural University, Bogor.

Brander LM, Beukering PV, Cesar HSJ. 2007. The recreational value of coral reefs: a meta-analysis. Ecol Econ 63: 209-218

Burke L, Reytar K, Spalding M, Perry A. 2011. Reefs at Risk Revisited. Defenders 74: 130 .

Dahuri R. 2003. Marine Biodiversity. Indonesia's Sustainable Development Asset. Gramedia Pustaka Utama. Jakarta. [Indonesian]

Djunaidi OS. 2011. Aquatic Resources; Potential, Problems, and Management. Widya Padjadjaran, Bandung. [Indonesian]

Douglass RW. 1975. Forest Recreation. 2nd ed. Pergamon Press.Inc., New York
English S, Wilkinson C, Baker V. 1994. Survey Manual for Tropical Marine Resources. ASEAN-Australian Marina Science Project: Living Coastal Resources. Australian Institute of Marine Science, Townsville.

Fandeli C. 2002. Natural Tourism Planning. Faculty of Forestry Universitas Gadjah Mada, Yogyakarta.

Gomez ED, Yap HT. 1988. Monitoring Reef Condition. In: Kenchington RA, Hudosn BET (eds). Coral Reef Management Handbook. UNESCO Regional Office for Science and Technology for SouthEast Asia, Jakarta.

Honey M. 2006. Forewordin "Le guide des destinations indigenes". Indige'needitions. Montpellier, France.

Ministry of Environment of Republic Indonesia. 2004. Ministry of Environment No.51 of 2004 on Marine Water Quality Standards for Marine Tourism. Ministry of Environment of Republic Indonesia, Jakarta. [Indonesian]

Natural Resource Conservation Center. 2010. Long-Term Management Plan of Marsegu Marine Island Natural Tourism Park in the period of 2011-2030. Westen Seram Region of Maluku Province, Ambon. [Indonesian]

Notji A. 2005. Marine Archipelago. Djamabatan, Jakarta. [Indonesian]

Plathong S, Inglis GJ, Huber M. 2000. Effects of self-guided snorkeling trails on corals in a tropical marine park. Conserv Biol 14 (6): 18211830

Principe P, Bradley P, Yee S, Fisher W, Johnson E, Allen P, Campbell D. 2012. Quantifying Coral Reef Ecosystem Services. U.S. Environmental Protection Agency, Office of Research and Development, Research Triangle Park, NC. EPA/600/R11/206,158pp.

Rhormens MS, Pedrini ADG, Ghilardi-Lopes NP. 2017. Implementation feasibility of a marine ecotourism product on the reef environments of the marine protected areas of Tinhare and Boipeba Islands (Cairu, Bahia, Brazil). Ocean Coast Manag 139: 1-11.

Sitanala MR, 2017. Ecological Potential and Compatibility Index of Aquatic Tourism Marine Tourism Park Kasa Island Maluku [Thesis]. University of Gadjah Mada, Yogyakarta. [Indonesian]

Supriharyono. 2007. Management of Coral Reef Ecosystem. Djambatan. Jakarta. [Indonesian]

Tourism Office of Maluku. 2015. Analysis of Maluku Tourism Market. Tourism Office of Maluku, Ambon.

Tratalos JA, Austin TJ. 2001. Impacts of recreational scuba diving on coral communities of the Caribbean island of Grand Cayman. Biol Conserv 102 (1): 67-75.

UNEP-WCMC. 2006. In the Front Line. Shoreline Protection and Other Ecosystem Services From Mangrove and Coral Reef. UNEP, Cambridge, UK.

Wabnitz CCC, Andres M, Cisneros-Montemayor, Hanich Q, Ota Y. 2018. Ecotourism, Climate Change and Coral fish Consumption in Palau: Benefits, trade-offs and Strategic Adaptation. Mar Pol 88: 323-332.

Walters RDM, Samways MJ. 2001. Sustainable dive ecotourism on a South African coral reef. Biodiv Conserv 10 (12): 2167-2179.

Yulianda F. 2007. Marine Ecotourism as an Alternative to ConservationBased Resources Utilization. Department of Waters Resources Management, Faculty of Fisheries and Marine Sciences, Bogor Agricultural University, Bogor. [Indonesian] 